\title{
NEW TYPES OF PONDS? CHANGING OF QUANTITY AND FUNCTION OF WATER BODIES IN RURAL BUILT-UP AREAS (PILSEN REGION, CZECHIA)
}

Jan Kopp, Jindřich Frajer, Marie Novotná ${ }^{1}$

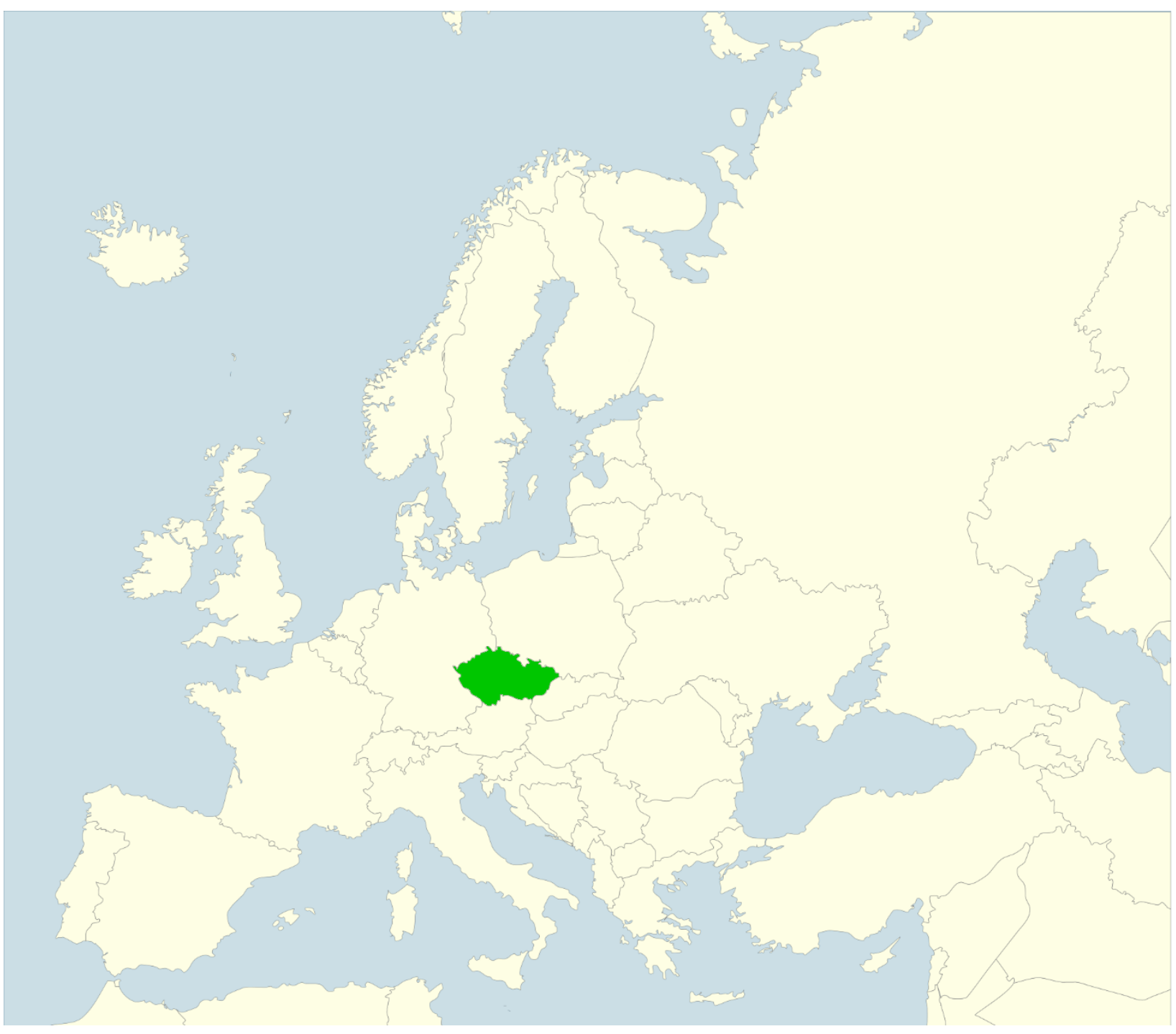

${ }^{1}$ RNDr. Jan Kopp, Ph.D., RNDr. Jindřich Frajer, Ph.D., Doc. RNDr. Marie Novotná, CSc., University of West Bohemia in Pilsen, 30614 Plzeň, Univerzitní 22, e-mail: kopp@kge.zcu.cz; jindrich.frajer@upol.cz; novotnam@kge.zcu.cz 
Abstract: This study is focused on the changing of areas of water bodies in selected villages of the Pilsen Region (Czechia). We researched several different types of rural settlements and three time horizons with the help of old maps, orthophoto maps and GIS tools. To capture the influence of their location within the urban system, we chose 15 places from four categories (inner suburban area, outside suburban area, rural area, periphery rural area) depending on their distance to the core of the Pilsen agglomeration. There is no significant change in the amount of water bodies between the first reference period (1838-1839) and the second period (1957-1963) in the selected settlements. However, the third period (2013-2015) is characterized by the emergence of a large number of small water bodies - swimming pools and garden ponds. Based on the results of our research we identified the declining importance of public water bodies in some of the settlements. However, we have identified a notable prevalence of garden ponds which have a more positive ecological impact than pools. The proportion of private water bodies (covered and uncovered pools and garden ponds) in the total area of water bodies in the rural settlements in most cases is less than $20 \%$, in the suburban settlements up to $100 \%$. Peripheral settlements have a below-average share of these water bodies. The difference between the number of pools in different settlements is related to the proportion of newly built houses there. Although there are relatively fewer pools in rural settlements, the difference compared to the situation in suburban settlements is not pronounced due to the change in lifestyle in rural areas and the change in functions of some villages to recreational areas. Influence of pools on water consumption is dependent on the individual exchange technology of water in swimming pools. Filling of the pool before the season can overload the capacity of the local water supply.

Keywords: swimming pools, garden ponds, rural settlements, water consumption, suburbanization, Pilsen Region

Abstrakt: Studie je zaměřena na změny vodních ploch ve vybraných sídlech Plzeňského kraje (Česko). Zkoumali jsme různé typy venkovských sídel a tři časová období s pomocí historických map, ortofotomap a nástrojů GIS. Abychom mohli diskutovat vliv polohy v rámci sídelního systému, vybrali jsme 15 sídel ze čtyř kategorií území (vnitřní suburbánní, vnější suburbánní, venkovské, venkovské periferní) podle vztahu k jádru plzeňské aglomerace. Mezi prvním sledovaným obdobím (1838-1839) a druhým obdobím (1957-1963) není významná změna vodních ploch ve vybraných sídlech. Třetí období, zachycující aktuální stav (2013-2015), se ovšem vyznačuje vznikem velkého počtu drobných vodních ploch - zahradních bazénů a jezírek. Na základě našeho šetření byl v některých sídlech identifikován upadající význam veřejných vodních ploch. Zajímavý je podíl rozlohy zahradních jezírek v některých sídlech, kde mají větší ekologický význam než vodní plochy bazénů. Podíl vodních ploch zahrad (krytých i nekrytých bazénů a jezírek) na celkové rozloze vodních ploch intravilánu venkovských sídel je ve většině prípadů menší než $20 \%$, v suburbánních sídlech až $100 \%$. Podprůměrný podíl těchto nových vodních ploch vykazují sídla periferní oblasti. Rozdíl mezi počtem bazénů $v$ jednotlivých sídlech souvisí s podílem nově vybudovaných domů. Ve vesnických sídlech je sice nižší relativní počet bazénů, ovšem vlivem změny životního stylu na venkově a rekreační funkce některých vesnic, není rozdíl oproti suburbánním sídlům výrazný. Vliv bazénů na spotřebu vody je závislý na individuální technologii výměny vody v bazénech. Rozhodující položkou je napouštění vody do bazénu před začátkem sezóny, což může přetěžovat kapacitu místního vodovodu.

Klíčová slova: bazény, zahradní jezírka, venkovská sídla, spotřeba vody, suburbanizace, Plzeňský kraj 


\section{Introduction}

In the current practice of water management attention is paid to water management in urban areas, but less so to rural settlements. In the historical context, the evolution of cities has been marked by securing water resources, drainage area, construction of flood protection and strengthening of the importance of water as a recreational and ecosystem elements of towns. Current trends of water management are being introduced in response to climate change in cities that integrate most of the existing water management requirements (Wong 2013; Ferguson et al. 2013; Kopp 2015). Experience in water management of cities can not be directly applied to rural settlements, which are not only smaller in size, but also have lower levels of water infrastructure, generally lower level of flood protection, and closer contact with the surrounding undeveloped landscape or other features surfaces in urban areas (ZMOS 2008).

The water bodies of the settlements have four basic meanings - (1) water management, (2) ecological, (3) climatic and (4) socio-cultural. Importance for water management is related to their functions, for example the reserve of water, fire reservoir, fish farming. The semi-natural habitats in the anthropogenic environment of settlements determine ecological importance of the water bodies. The importance of climate change is related to the ability of thermoregulation of the landscape. This aspect is very important in a period of climate change. Aesthetic, recreational, historical and architectonic values of the water bodies of the settlements define socio-cultural significance.

Currently $84 \%$ of the population of Pilsen Region is supplied with water from the public water works (ČSÚ 2015). The proportion of residents who have homes connected to the sewage system is $83 \%$ (Čsú 2015). In rural areas, access to public water infrastructure is lower than the average across the region. Insufficient capacity of storm drains and low retention capacity of the agricultural landscape provokes flooding when torrential rainfalls flood parts of the villages that otherwise would not be threatened by floods from their local watercourses (Hysková 2003; Kopp 2007). Meanwhile land use changes in rural communities continue to be affected by the ongoing "urban" trend - the changing use of private land for recreational function or expansion of impervious surfaces in public spaces that are reaching the city standards in the proportion of paving and asphalt. Consequently, it is possible to expect to increase problems in connection with the trends of climate change. The basic problem we see is the potential for growing summer water consumption for the operation of recreational gardens with pools installed in many places, which may lead to inadequate water supplies for normal daily operation needs of households. In our research we have therefore tried to identify these changes in the development of rural areas in the Pilsen Region using a sample survey of some settlements and an assessment of the development of water bodies in their urban areas. The research should help find answers to the following questions:

1) How has the structure and function of aquatic areas of rural settlements changed due to the historical development from the 19th century to the present day?

2) Are these changes dependent on the location of the rural settlements in the settlement system?

3) What are the potential consequences of changes to surface water for water consumption?

\section{Theoretical background}

\subsection{The historical significance of water bodies in rural communities}

The connection between human settlements and water resources can be traced throughout history. The first lakes that originated in the Czech Republic were closely connected with human settlements and served as water reservoirs for various purposes (Šusta, Mokrý 1931). In addition to the traditional functions of retention or fish breeding water bodies in rural settlements also served an important function of fire fighting, energy (water mills and metal work), and in farming where water bodies served as a source of water for livestock and water fowl. In the summer water from ponds irrigated meadows. In winters ice harvested from water bodies was used in restaurants, butchers or for medical purposes (Frajer 2015). The water tank feature in the builtup parts of villages remains controversial since these reservoirs are often polluted by sewage 
water meaning they can spread various diseases, as demonstrated by recent studies from developing countries (Mukherjee et al. 2011). Historical sources show that people understood and used any concentration of surface water in the countryside. Muir (2004) states that it is often difficult to distinguish between water bodies created by people and nature. Apart from meres, flashes and kettle holes, Muir also distinguishes between dew ponds, mill ponds, ponds hammer, armed ponds and fishpond depending on the water bodies' use. The fine resolution of individual water bodies in rural communities and the surrounding countryside is also found in Josef register from 1789, when the next to "ponds" (breeding, mill, etc.), it also referred to "small ponds" (mostly village ponds with fireproof function and waterholes for cattle located in the middle of the village), "puddles" and "water storage" which were apparently concentrations of water in ground depressions (Frajer 2013). This primitive method of trapping water in depressions is found in settlements with a lack of other water resources (Jíhlavec 1978). Modernization processes in society during the 19th century is also reflected in the change of use and extent of surface water in the countryside (Havlíček et al. 2014), and also in villages (Frajer 2015).

\subsection{Changes of water bodies as part of the transformation of rural areas}

Village ponds belong to the traditional image of our villages as one of the visual elements of the square. However presently the village center pond, if it still exists, is already losing its functional and esthetic importance. Many of these water bodies suffer from a lack of care or have been converted into technical tanks for fire protection. In research on current representations ideal rural life (Pospěch et al. 2015) water bodies were not significantly part of village identity. In the second half of the twentieth century public pools became an important aspect of social life. Their importance in some villages is still preserved especially if the pool is cared for by the village or sports clubs. In rare cases we can see public swimming pools directly in place of the village ponds, a trend which is related to the changing function of the village square in general.

Changes in the use of the gardens in the countryside is also related to the change in lifestyle that approximates life in the city. There are decreasing demands on agricultural land use around the house as a place for poultry, agricultural machines, stored manure, and gardens where people grow their own vegetables or hay. People prefer private space around the house as a place of rest and recreation, their work activities are geared to the cultivation of ornamental gardens.

This significant transformation occurs gradually with the changing sociological structure of rural settlements. Changing personal preferences, careers, and increase of recreational activities have an impact on the transformation of rural houses and on changes in function and appearance of the surrounding land. Similarly to Poland, in the Czech Republic such changes are due to significant socio-economic transformation of rural areas during the post-socialist period (Bański \& Wesołowska 2010).

Recreational gardens were already being established by cottage owners and vacationers in villages during the socialist period. Gradually this transformation also occurs in residential areas of villages. Generational change and the reduction of the proportion of people who are employed in agriculture is one of the factors. In her analysis of rural areas in the municipality Renče (District Pilsen-South) Loudová (2012) found the new land uses associated with the new rural lifestyle are more common in central villages while smaller peripheral settlements mostly retain their original agricultural land uses.

The intensity of migration to rural settlements depends on their location in relation to urban agglomerations. We can observe different changes - from intense transformation of the function of settlements in the village landscape due to suburbanization (Sýkora \& Mulíček 2012; Ouředníček et al. 2013) to the weak effect of counter-urbanization (Pallarès-Blanch et al. 2014; Šimon 2014) or amenity migration (Kopp et al. 2009; Bartoš et al. 2011). Specific functional areas on the outskirts of cities are gardening communities that are in the new millennium transforming into private recreation areas with the increase in cottages, gardens and swimming pools (Spilková \& Vágner 2016). The recreational use of gardens, their landscaping and especially the size and quality of swimming pools depend on the socio-demographic characteristics of owners (Smallbone et al. 2011; Syme et al. 2004). Consequently the economic status of families affect the amount of water consumed for the garden and pool (Chang et al. 2010; Domene et al. 2015). 
We expect that the proportion of gardens used for recreational and decorative purposes will decline as we move away from suburban low-density residential areas on the edges of cities, and onward to the more distant rural settlements on the periphery of agglomeration (Domene et al. 2005; Radford \& James 2013). In villages far from urban agglomerations the share of recreational gardens will depend on the proportion of holiday homes.

\subsection{Pools as a new phenomenon in rural settlements}

The Czech Republic is among the countries where garden pools are very popular. According to the European Union of Swimming Pool and Spa Associations, the Czech Republic ranks third in Europe behind Spain and France, and ahead of Slovakia, Hungary and even Germany, in the number of pools per 1000 inhabitants. The current number of pools in the Czech Republic (again excluding portable rubber pools) reaches over 200000 (Bach 2014; Váchal 2016). If we included the portable rubber pools the number could, in our estimate based on partial statistics of sales, amount to 300000 to 350000 pools. While in the 1990s the purchase of a pool was a sign of luxury, during the last decade the situation has changed. The swimming pool has become a part of our gardens; the economic status of the owner is reflected in the quality of pool equipment. The number of swimming pools installed has begun to grow faster (Bach 2014; Váchal 2016). Several factors contribute to this new trend: (a) swimming pools are cheaper due to the growth of production efficiency and increasing competition, (b) decreasing holidays by the sea in the wake of the economic crisis, (c) increasing summer heat (e.g. 2015).

Pools are a new phenomenon, which is part of the overall transformation of rural gardens in other areas of Europe, especially in the Mediterranean. Extension of new types of gardens and pools are addressed in detail in the study of the metropolitan region of Barcelona (Domene et al. 2005; Domene 2014), which identifies new growth of "Anglo" type gardens at the expense of traditional Mediterranean gardens in this region of Catalonia. Geographical distribution of the new recreational gardens and pools is dependent on household income: in the richer parts of the region (narrow suburban zone) the transformation is intense with higher demand for water. Remote and economically poorer peripheral parts of the metropolitan region maintain more traditional gardens with lower water needs (Domene et al. 2005; Vidal et al. 2011; Domene 2014).

In the metropolitan region of Rome Zambon et al. (2015) found a heterogeneous structure of expansion of the new types of residential areas with swimming pools. The authors use the higher density of pools in the settlements as an indicator of suburbanization and the transformation of the traditional settlement system, which results in the expulsion of endemic landscape elements (Zambon et al. 2015). The density of pools on the Mediterranean coast is affected not only by climate but also by tourism establishments, and is therefore not comparable to those of Central Europe.

Another interesting debate is whether the installation of private pools substitutes for the lack of public pools. A study in semiarid Tucson found there is a relationship between the need for water for private gardens and pools and the lack of public space with similar functions (Halper et al. 2015). The results can be interpreted as a planning goal to lower the city's water consumption by increasing public swimming pools and spaces like gardens (Halper et al. 2015). In the Czech rural environment this is relevant to the existence and quality of public swimming pools whose level of care is uneven across communities. While various local governments using public funding bolstered by EU subsidy programs created many modern public swimming areas, sometimes near natural water bodies, at the same time many public swimming pools disappeared or have been demoted to the fire tanks with doubtful possibilities for swimming. Water bodies continue to be in high demand because they fulfill an important visual aesthetic role in urban areas. In general water bodies in private gardens and public parks are an important aesthetic element that is irreplaceable with artificial glass or mirror substitutes (Nasar \& Li 2004).

\subsection{Effect of water bodies on water management}

The development of new recreational areas, such as golf courses and swimming pools, in the landscape along the Mediterranean coast is viewed not only as landscape change but also as a factor influencing the increase in demand for water in regions stressed by climate change. 
Automated identification of pools from satellite images have been developed to determine the impact of pools on water consumption (Wolf \& Hof 2013). Based on this method it was concluded that along the Spanish Mediterranean coast the significant extension of gardens and pools have increased water consumption. In some areas depending on climate conditions and evapotranspiration the water consumption exceeds the average for irrigation of fields in Spain (Hof \& Wolf 2014). Pools contribute $8-15 \%$ of this water consumption. Another issue is the energy consumption in the operation of pools, especially when heated water is used (Mousia \& Dimoudi 2015).

A comparison of selected US cities revealed significant geographic differences in the development of water bodies (garden ponds, fountains, pools) in the gardens of new residential houses. The predominant trend is the increase of garden water features. However, when analyzing household consumption water, the water for pools was calculated apart from landscaping water use, even if both uses are often seasonal in nature (DeOreo 2011).

An important part of the water needs in areas of residential development depends on climate. The water demand for irrigation varies in close connection with daytime air temperature. Lanscape watering can be done with water that is used for regular exchanges in the pool. Great attention to this issue is paid in areas with hot summers, where water consumption for landscaping approaches $50 \%$ of total household consumption (Salvador et al. 2011). In regions with significant impacts of climate change, limits on pumping water for landscaping irrigation are being introduced already. An Australian study shows a greater impact of such limits on water consumption in public parks than on irrigation of private gardens (MacDonald et al. 2010).

Water demand for pools is dependent on water purification technologies most of which recommend the replacement water for hygienic reasons at the rate of 30 liters per pool user per day. On days with high temperatures we must also reckon with the influence of water loss by evaporation. Evaporation of pool water affects the microclimate in the immediate vicinity of the pool, and in theory the mesoclimatic range, and is related to the rate of water replenishment in swimming pools. The influence of surface water resources and landscape irrigation on mesoclimatic conditions known as the urban heat island is well documented (Guhathakurta \& Gober 2010). In rural settlements that have less surface water their effect is only microclimatic.

In terms of climatology pools are a specific environment of water surfaces defined by shape, surface albedo, and possibly by artificial turf on the deck. Therefore their evaporation rates cannot be based directly on the common values of water evaporation. Shah (2012) models the evaporation of the pools on the basis of heat balance of water and air, taking into account its relative humidity. Attention is devoted to deriving the dependence of evaporation from the pool to the actual weather conditions on the basis of empirical measurements (Asdrubali 2009). The results could be useful once verified for use in Central European climate conditions.

\section{Methodology}

The assessment of the development of water bodies in rural settlements was made by analyzing developments in their structure in selected small settlements in the Pilsen Region. To capture the influence of their location within the urban system, we chose 15 places from four categories depending on their distance to the core of the Pilsen agglomeration (Tab. 1, Fig. 1). We chose seven settlements that are affected by residential suburbanization, three of which are strongly affected by the increase in houses and people (zone 1). Of these Koterov and Malesice are currently administratively part of the city of Pilsen. In the next four selected settlements (zone 2) the manifested suburbanization processes are more modestly (Ouředníček 2012; Kopp et al. 2013). The more distant settlements were selected evenly from areas north and south of Pilsen in the rural parts of the region. Selected rural settlements are distinguished by their position in rural areas: four are closer to Pilsen (zone 3) and four more distant (zone 4). Zone 4 settlements are located in the border areas of the region, beyond the influence of other urban areas and can therefore be classified as peripheral. Development of the population in selected settlements is documented in figure 2 , with categories relevant to an analysis of water bodies. 


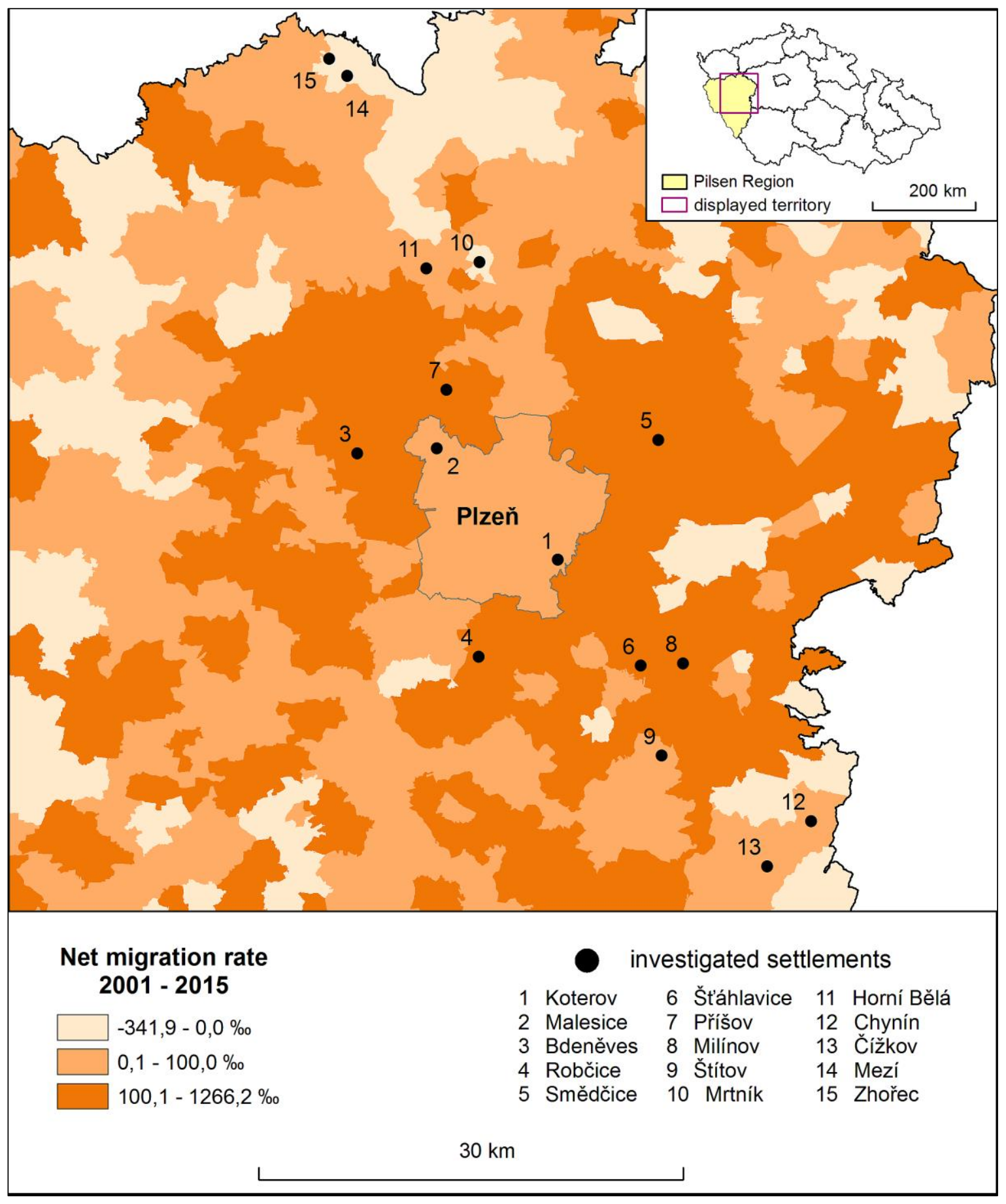

Fig 1. Geographical location of studied settlements. Source: own processing by Czech Statistical Office 
Tab 1. Categorization of studied settlements and population development. Source: own processing by Ouředníček 2012; Kopp et al. 2013; Čsú 2015a

\begin{tabular}{|l|l|r|r|r|}
\hline \multirow{3}{*}{ Settlements category } & \multirow{3}{*}{ Settlement } & \multicolumn{3}{|c|}{ Year } \\
\cline { 2 - 5 } & & 1869 & 1961 & \multicolumn{1}{c|}{2013} \\
\hline \multirow{4}{*}{ Zone 1 - inner suburban area } & Koterov & 371 & 585 & 713 \\
\cline { 2 - 5 } & Malesice & 502 & 432 & 712 \\
\cline { 2 - 5 } & Bdeněves & 420 & 441 & 626 \\
\hline \multirow{5}{*}{ Zone 2 - outside suburban area } & Robčice & 179 & 168 & 180 \\
\cline { 2 - 5 } & Smědčice & 237 & 260 & 266 \\
\cline { 2 - 5 } & Št'áhlavice & 437 & 450 & 492 \\
\cline { 2 - 5 } & Př́šov & 216 & 286 & 301 \\
\hline \multirow{5}{*}{ Zone 3 - rural area } & Milínov & 418 & 300 & 181 \\
\cline { 2 - 5 } & Štítov & 194 & 91 & 102 \\
\cline { 2 - 5 } & Mrtník & 288 & 345 & 331 \\
\cline { 2 - 5 } & Honí Bělá & 674 & 429 & 295 \\
\hline \multirow{3}{*}{ Zone 4 periphery rural area } & Chynín & 204 & 107 & 41 \\
\cline { 2 - 5 } & Čížkov & 551 & 250 & 134 \\
\cline { 2 - 5 } & Mezí & 135 & 68 & 56 \\
\cline { 2 - 5 } & Zhořec & 129 & 87 & 57 \\
\hline
\end{tabular}

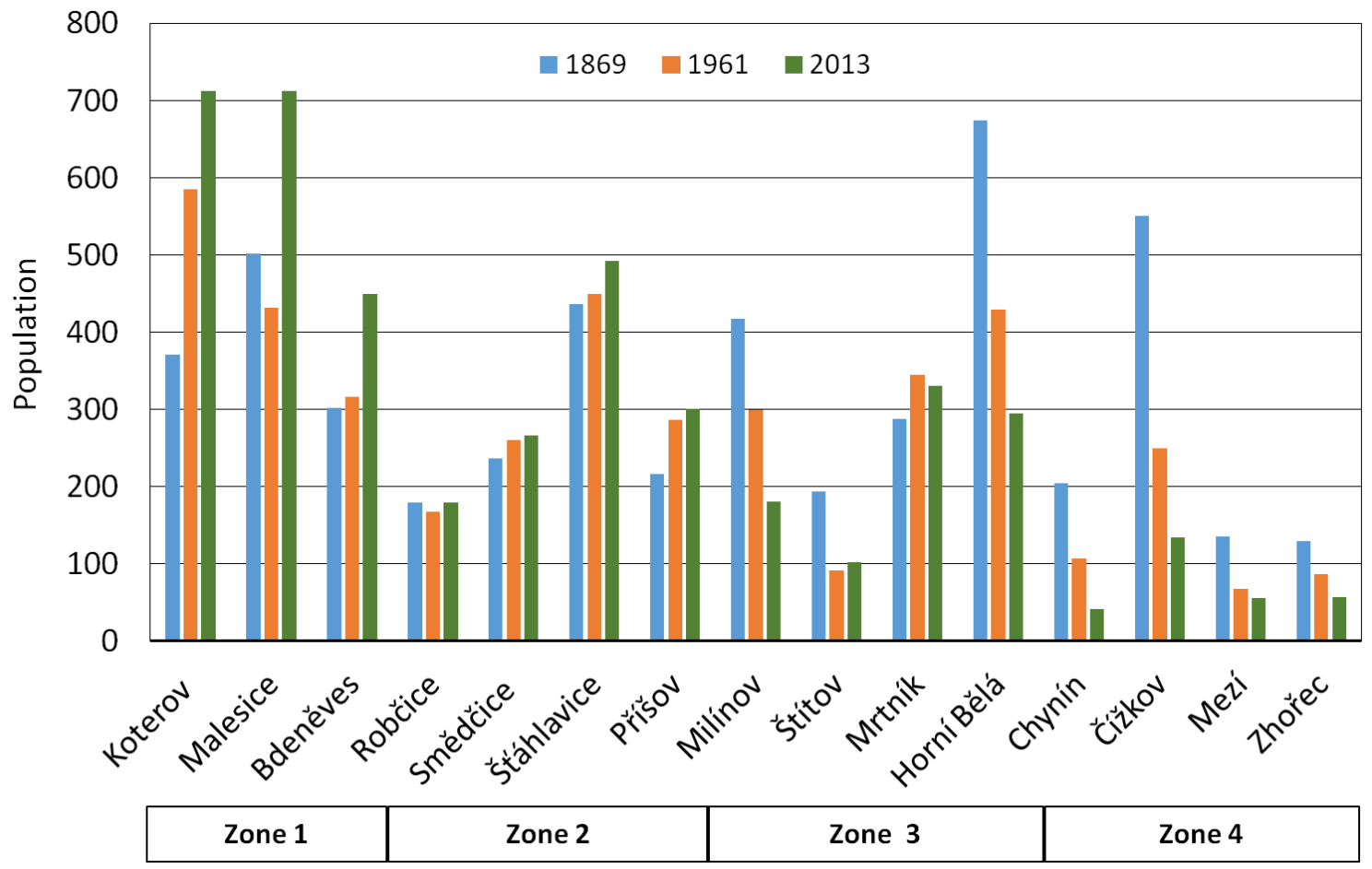

Fig 2. Development of the population of studied settlements. Source: own processing by ČSÚ 2015a

The sources of information on water bodies are: Imperial Imprints of the Stable Cadastre maps at a scale of 1:2880 from 1838-1839 and military topographic maps in the S-1952 system (19571963 ) in the scale 1:10 000, both from archival files of the Central Archive of Land Surveying and Mapping. Current status of water bodies has been identified on aerial photos (ČÚZK 2016a; Seznam.cz 2016), images dated from May to July (2013-2015). 
Raster historical resources were georeferenced, then the current water bodies were classified and digitized using ArcGIS Desktop 10.3. The digitization of portable rubber pools was also done even though their identification was sometimes difficult (Fig. 3). We are aware that the number of portable pools can vary during the season. In all of the settlements we performed analyses of the availability and status of public pools with our students during the course of their field work exercises in April 2016.

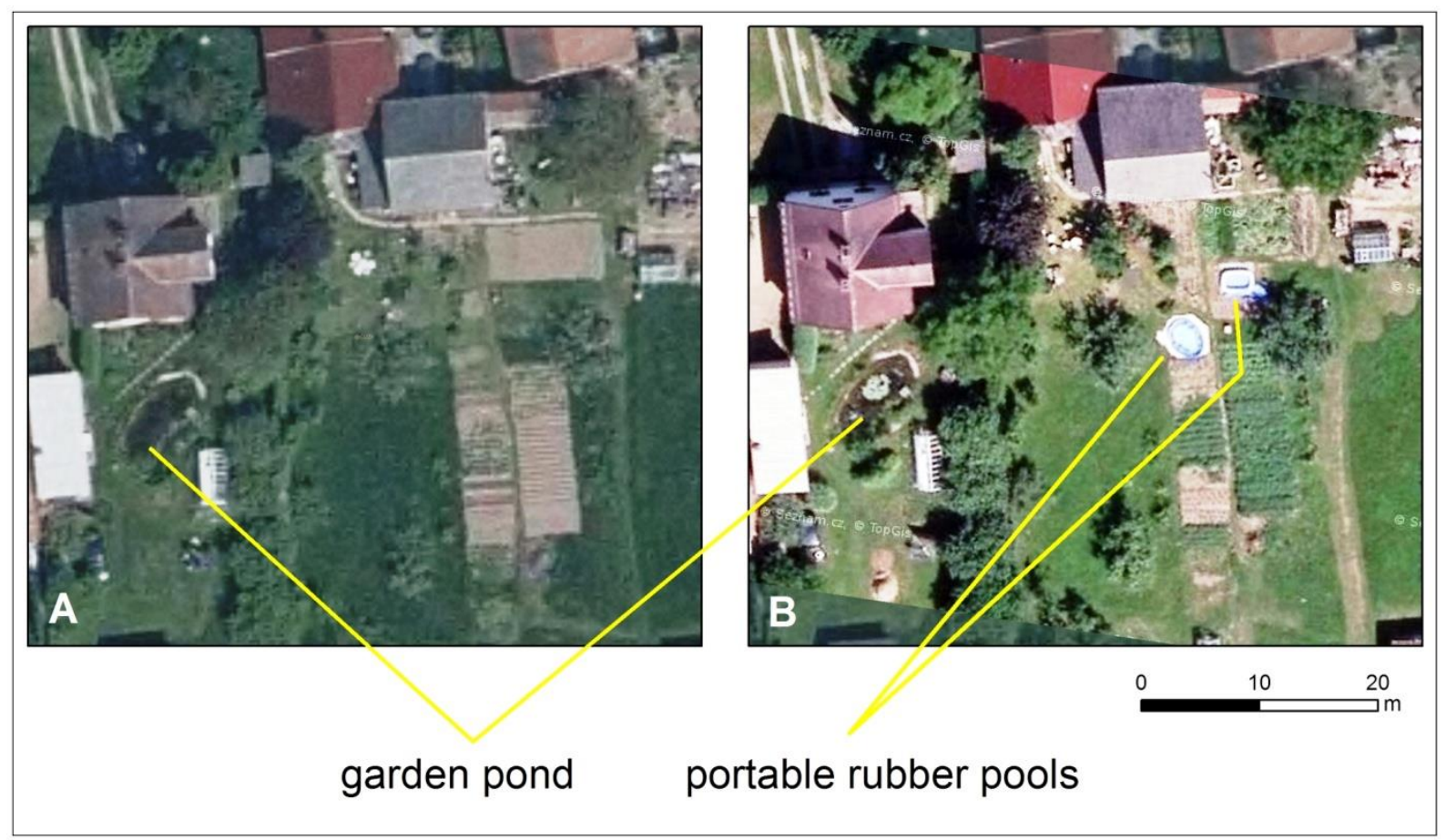

Fig 3. Same area on the ortophoto maps from different months of the same year ( $A$ - May, $B-J u n e / J u l y)$. We counted on maximum number of water bodies (B). Source: A) ČÚZK (2016a), B) Mapy.cz (Seznam.cz 2016)

The area of interest within settlements is the largely built-up parts of the settlement. We included gardens, roads, private and public green areas, water streams, and surface water in the built-up areas and their adjacent areas forming a compact unit. The boundaries between built-up and outside landscape areas were plotted in GIS based on current cadastral maps and aerial photos joined to form an outer perimeter of built-up and adjacent areas. Contents of the built-up areas form the elements of the polygons. The number of houses in each urbanized settlement is found by summing address points (places) from the register of territorial identification, addresses and real estate (RUINAN), shown in the urban settlements. This address space RUINAN we received in exchange format from the CUZK Geoportal (ČÚZK 2016b).

For each time period we determined and subsequently compared the indicators of the representation of water surfaces in urban settlements: the number of water areas, the sum total of water area, the relative proportion of water area to built-up area of settlements. For the evaluation of the current status of water bodies in settlements that had a high number of garden pools, we tested other relative indicators: number of pools per 100 people in the settlement, and a number of pools per 100 houses (including recreational facilities).

The influence of water bodies on settlement water supply was analyzed using a general assessment of changes in evaporation and by taking into account the water needs for the operation of swimming pools. This study does not address the actual evaporation, but uses reference values of evaporation from climatological stations in the country. For example we can use evaporation data (standardized time series 1971-2000) for our area of interest from the closest station in Cheb (Fig. 4). The data show a deficit of water in the summer because of the difference between evaporation and precipitation. If we take the average values in the area of interest (Tolasz 2007) we may have a deficit of water of up to $200 \mathrm{~mm}$ in the aggregate over 
the course of a dry summer (April to September). Using water surface evaporation of course neglects the influence of water body area and microclimate conditions.

Projected $21^{\text {st }}$ century climatic trends in the Czech Republic show increasing of the potential evapotranspiration and decreasing of the precipitation in the summer months. Annual potential evapotranspiration increases, according to scenarios between the period 1961-1990 and 20102039 by 6\% (Kohut et al. 2011), most grows in November, April and June (VInas 2015).

Tab 2. The approximate impact of climatic conditions on the hydrological balance of water bodies in the area of interest (averages standardized time series 1971-2000). Source: own processing by Tolasz (2007)

\begin{tabular}{|l|c|c|}
\hline Water balance element & Year & April - September \\
\hline Average total precipitation $\mathrm{H}_{\mathrm{S}}(\mathrm{mm})$ & $500-600$ & $300-400$ \\
\hline Average total evaporation $\mathrm{H}_{\mathrm{E}}(\mathrm{mm})$ & $575-625$ & $475-525$ \\
\hline Average total reference evapotranspiration $(\mathrm{mm})$ & $575-625$ & $450-500$ \\
\hline Average total water balance $\mathrm{H}_{\mathrm{S}}-\mathrm{H}_{\mathrm{E}}(\mathrm{mm})$ & $-125-(+25)$ & $-225-(-75)$ \\
\hline
\end{tabular}

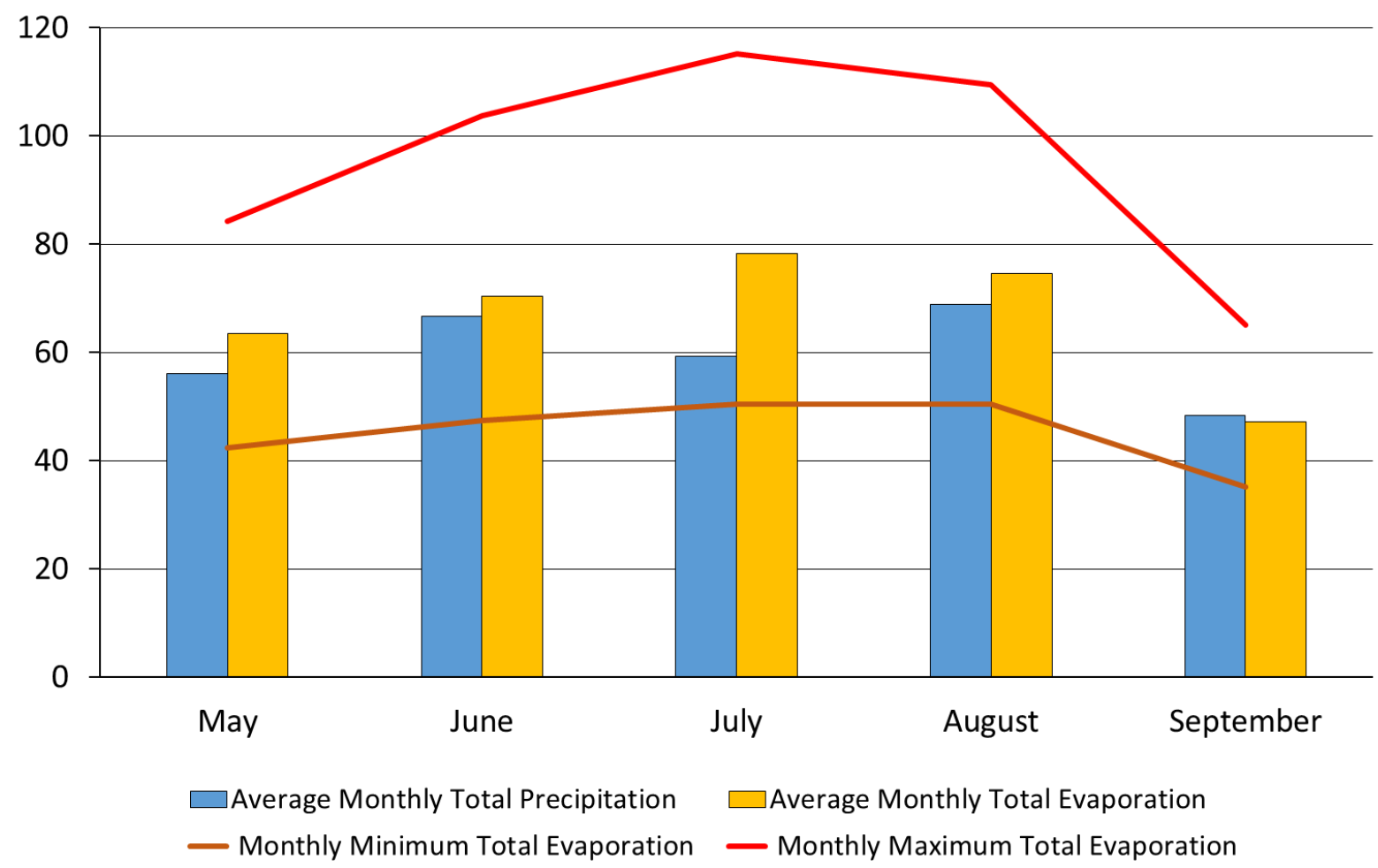

Fig 4. Average monthly total precipitation and water surface evaporation in vegetation season (standardized time series 1971 - 2000) at Cheb climatology station. Source: own processing by Kohut et al. (2013) and Czech Hydrometeorological Institute

\section{Results and Discussion}

Statistics on water bodies in the selected settlements show that there is no significant change between the first reference period (1838-1839) and the second period (1957-1963). However, the third period (2013-2015) is characterized by the emergence of a large number of small water bodies on private land. We can demonstrate an increase of garden modernization, the installment of pools, ornamental ponds in the gardens, recreational, and decorative features (Fig. 5, Fig. 6). 


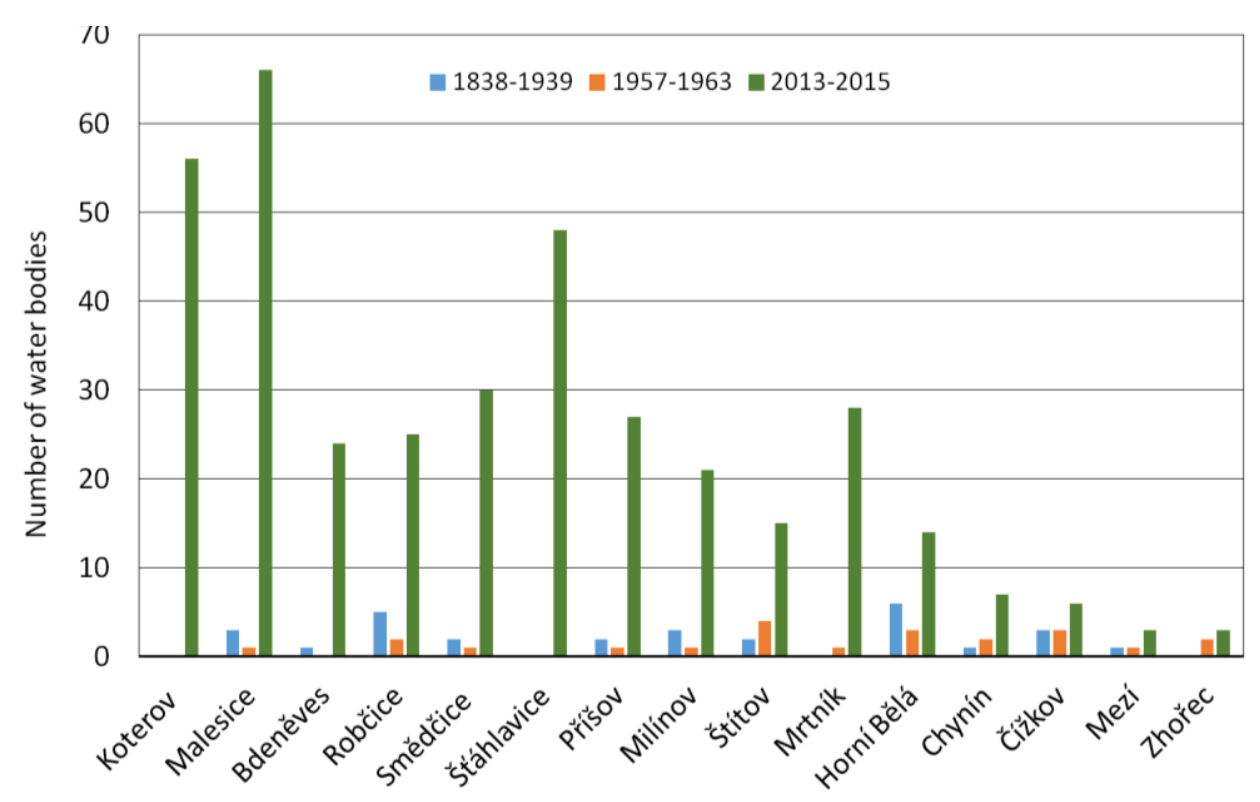

Fig 5. Development of water bodies number in settlements. Source: own processing

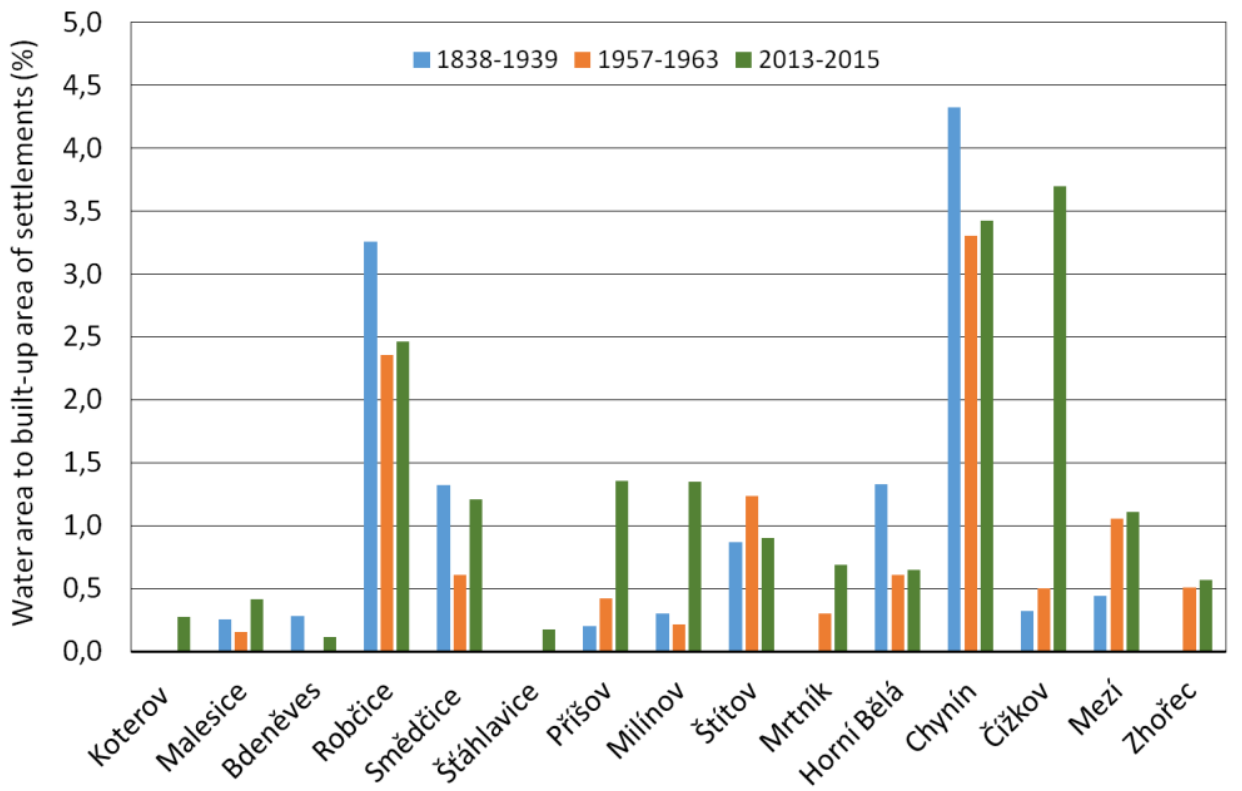

Fig 6. Development of relative proportion of water area to built-up area of settlements (\%). Source: own processing

In some settlements we noted an increase in water areas beyond private gardens. Various public water areas (fire reservoirs, ponds) used mostly for fish farming, or retaining runoff from larger rainfall events (Tab. 3, Tab. 4). During winters these water bodies serve as ice rinks for locals. However, most of these water bodies cannot be used for bathing. Our fieldwork revealed that only three settlements have functional public swimming pools. It would be interesting to see whether expanding public swimming facilities would limit the number of private pools, as was suggested by some studies from different geographic environments (Halper et al. 2015).

The examples from the settlements in our study cannot confirm this relationship. We believe that the trend toward private recreation areas is related to changes in lifestyles and the individualization of leisure activities in both suburban and rural areas. There is a correlation between number of water bodies and the prevalence of recreational houses in rural settlements. The periphery of the Pilsen Region has a high proportion of holiday homes especially in South Brdy. For example, Chynín has a larger proportion of holiday homes (54\%) than permanently occupied residences, which significantly increases the number of private recreational water bodies counted per 100 inhabitants. 
Tab 3. Typology and statistics of current water bodies out of gardens (2015). Source: own processing

\begin{tabular}{|c|c|c|c|c|c|c|}
\hline \multirow[b]{2}{*}{ Type } & \multirow[b]{2}{*}{ Function } & \multirow[b]{2}{*}{ Biotope types } & \multirow{2}{*}{$\begin{array}{l}\text { Total } \\
\text { number }\end{array}$} & \multicolumn{3}{|c|}{ Area $\left(\mathrm{m}^{2}\right)$} \\
\hline & & & & Maximum & Minimum & Average \\
\hline $\mathrm{F}$ & fish ponds & $\begin{array}{l}\text { eutrophic and } \\
\text { mesotrophic waters }\end{array}$ & 17 & 9568 & 71 & 1625 \\
\hline W & water reservoirs & mesotrophic waters & 14 & 2037 & 21 & 484 \\
\hline$S$ & $\begin{array}{l}\text { public swimming } \\
\text { pools }\end{array}$ & $\begin{array}{l}\text { oligotrophic and } \\
\text { mesotrophic waters }\end{array}$ & 3 & 1305 & 358 & 801 \\
\hline
\end{tabular}

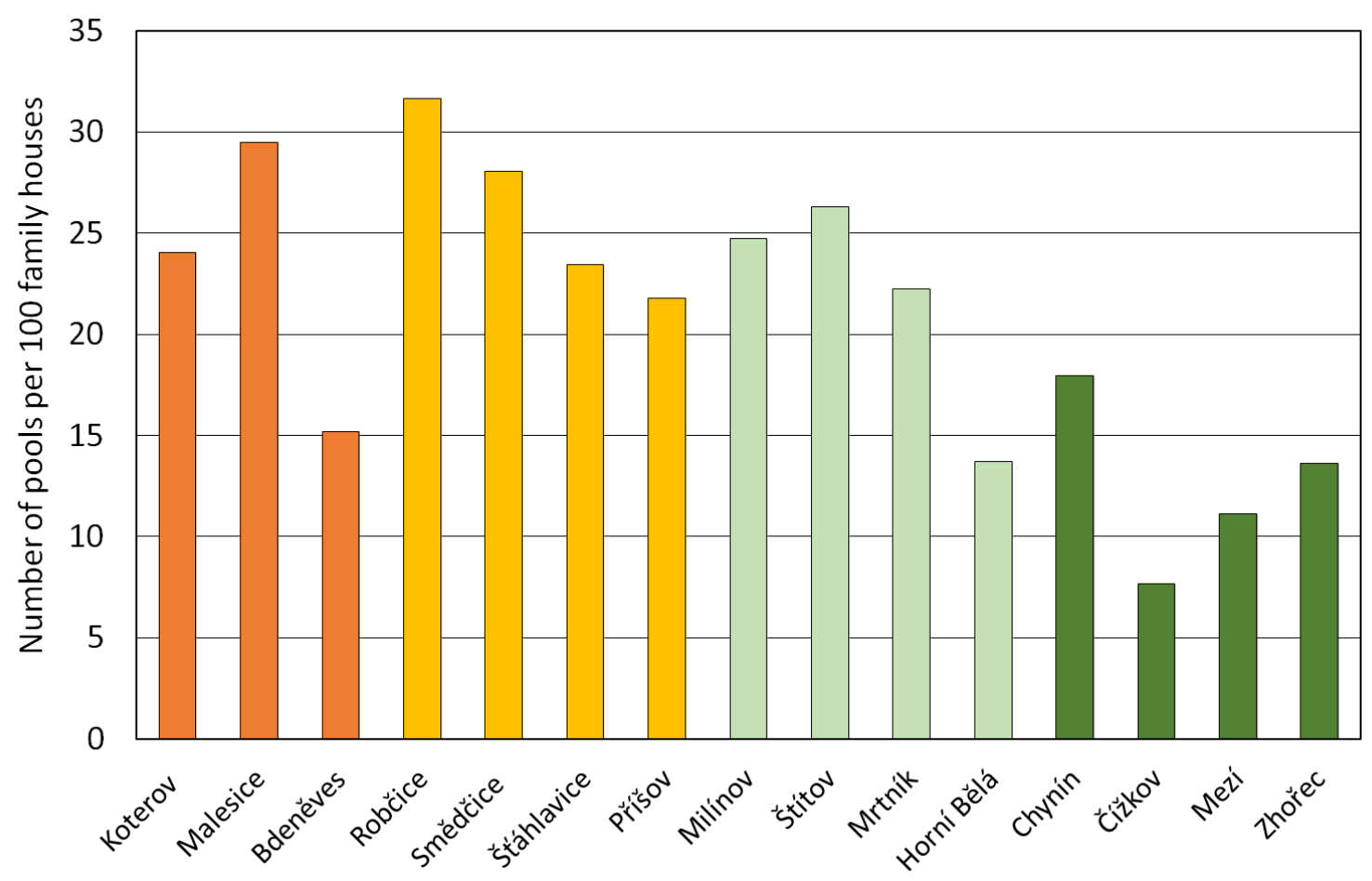

Fig 7. Number of swimming pools per 100 family houses. Source: own processing

We found a relatively higher share of private swimming pools (or even garden ponds) in the gardens of settlements in the suburban area of the city of Pilsen, particularly in Malesice, Robčice and Smědčice (Fig. 7, Fig. 8, Fig. 9, Tab. 4). The difference between the number of pools in different settlements is related to the proportion of newly built houses there. Its assumed that home owners in these places have sufficient financial resources to purchase recreational facilities. Although there are relatively fewer pools in rural settlements the difference compared to suburban settlements is not pronounced due to a change in lifestyle in rural areas and the change in functions of some villages to recreational areas. To confirm the relationships between influence of socio-economic characteristics of households, the location settlements in the agglomeration and the expansion of private pools found in other studies (Domene 2014, Zambon et al. 2015) we would need more detailed field research and more detailed data about local inhabitants.

The proportion of private water bodies (by covered and uncovered pools and garden ponds) in the total area of water bodies of rural settlements in most cases is less than $20 \%$, in the suburban settlements up to $100 \%$ (Fig. 8). Peripheral settlements have a below-average share of these water bodies. Conversely suburban areas have a larger share, and also a lower area of public water bodies. Although the share of private water bodies is relatively small given the size of the settlement area, their increased importance in the suburban zone is more evident than in distant rural communities (Fig. 9). In some settlements there is a notable prevalence of garden ponds, which have a more positive ecological impact, over pools (Goddard et al. 2010). 
Tab 4. Water bodies in current settlements (2015). Type: $F$ - fish pond, $W$ - water reservoir, $S$ - public swimming pool. Source: own processing

\begin{tabular}{|c|c|c|c|c|c|c|c|c|}
\hline 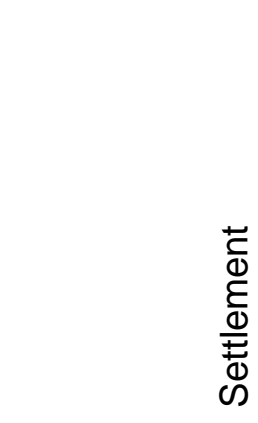 & 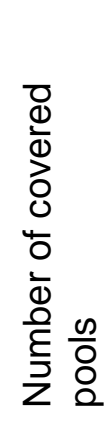 & 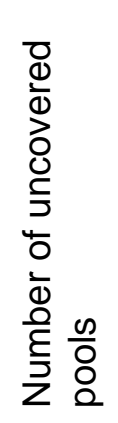 & 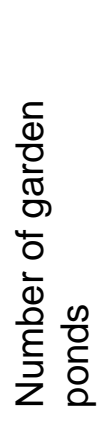 & 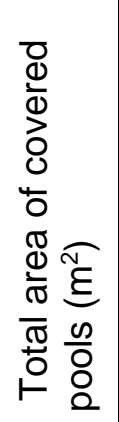 & 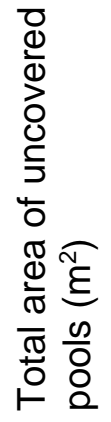 & 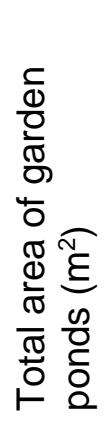 & 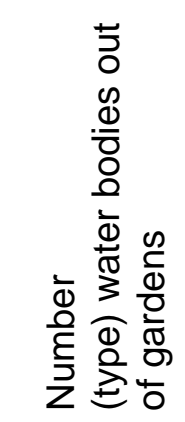 & 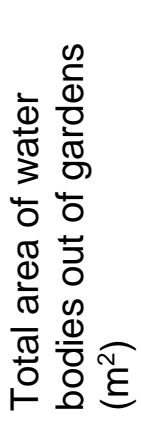 \\
\hline Koterov & 7 & 49 & 0 & 165 & 646 & 0 & 0 & 0 \\
\hline Malesice & 21 & 45 & 4 & 478 & 736 & 45 & $1(S)$ & 741 \\
\hline Bdeněves & 6 & 18 & 2 & 104 & 274 & 36 & 0 & 0 \\
\hline Robčice & 5 & 20 & 3 & 102 & 274 & 317 & $3(\mathrm{FSW})$ & 5,629 \\
\hline Smědčice & 12 & 18 & 2 & 287 & 234 & 196 & 4(FFWW) & 3,161 \\
\hline Št'áhlavice & 5 & 43 & 1 & 102 & 538 & 26 & $1(\mathrm{~W})$ & 381 \\
\hline Příšov & 8 & 19 & 7 & 220 & 350 & 252 & 3(FWS) & 3,337 \\
\hline Milínov & 3 & 18 & 0 & 56 & 224 & 0 & $3(\mathrm{FFW})$ & 2,702 \\
\hline Štítov & 0 & 15 & 2 & 0 & 154 & 83 & $3(F W W)$ & 1,686 \\
\hline Mrtník & 5 & 23 & 2 & 95 & 325 & 62 & $3(F W W)$ & 1,436 \\
\hline Horní Bělá & 2 & 12 & 3 & 39 & 149 & 55 & 3(FFF) & 1,668 \\
\hline Chynín & 1 & 6 & 3 & 11 & 48 & 64 & $2(F W)$ & 3,468 \\
\hline Čížkov & 2 & 4 & 1 & 22 & 64 & 120 & 4(FFFW) & 11,091 \\
\hline Mezí & 0 & 3 & 0 & 0 & 61 & 0 & $1(F)$ & 1,310 \\
\hline Zhořec & 0 & 3 & 0 & 0 & 25 & 0 & $3(F W W)$ & 545 \\
\hline
\end{tabular}

When we calculate the influence of the installation of pools on evaporation, it is important to consider that evaporation is also present in gardens without pools. Here we consider the so-called reference evapotranspiration value (close to the values of water surface evaporation) multiplied by the crop coefficient. This coefficient is $0.70-0.85$ for lawns for example (Allen et al. 1998; Duffková 2003). After the introduction of surface water on instead of lawns evaporation will increase by $15-30 \%$, therefore we can expect an increase in evaporation by $30-60 \mathrm{~mm}$ in the aggregate area of interest during the summer season. If we translate this to the need to refill pool water, this value would be $30-60 \mathrm{I} / \mathrm{m}^{2}$ of water surface during the April to September time period.

The largest areas for uncovered pools has been detected in Malesice $\left(736 \mathrm{~m}^{2}\right)$. If we estimate the difference between evaporation from water surfaces and precipitation to be $200 \mathrm{~mm}$ for the summer season (Tolasz 2007; Kohut et al. 2013), only the uncovered pools in Malesice contribute a loss of $147 \mathrm{~m}^{3}$ of water. The change of land use from the grassy areas to pool contributes between 22-44 $\mathrm{m}^{3}$. Considering the average consumption of one inhabitant (about 100 I /day) the water loss due to evaporation from pools is equivalent to water consumption of about eight people during the summer season. Therefore the water exchange technology (at the hygienic level of 30 I /day per person) is decisive in lowering the impact of pools on water supply (SPASA 2011). In practice, this exchange technology combines cleaning pool filters while supplementing the water deficiency resulting from evaporation. However water loss to evaporation on the level of water consumption for pools is relatively small in Czech climatic conditions. More importantly garden water features (pools or ponds) partly contribute to positive thermoregulation of settlements areas (Guhathakurta \& Gober 2010). 


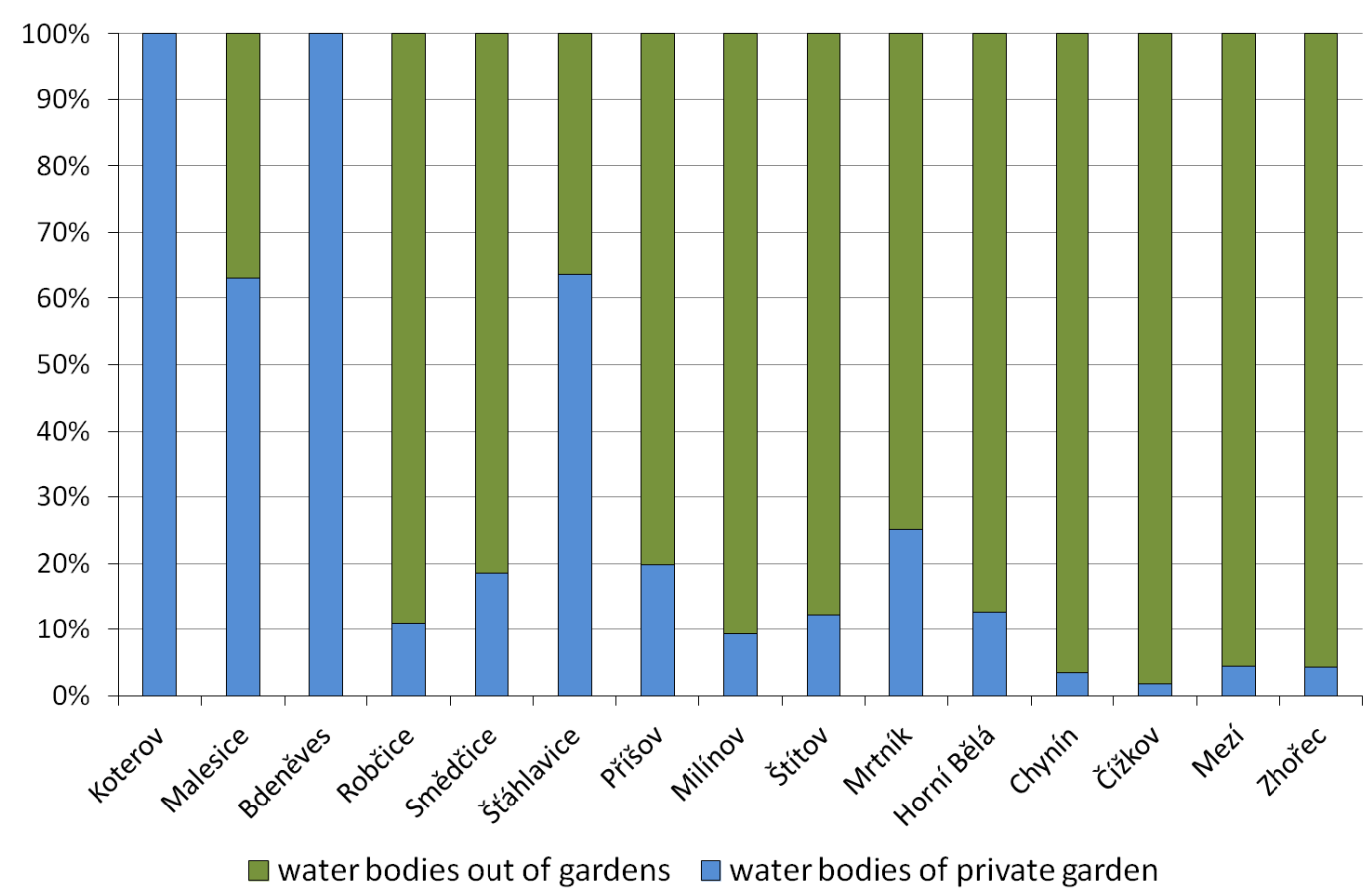

Fig 8. Proportion of private water bodies in the total area of water bodies of settlements (\%). Source: own processing

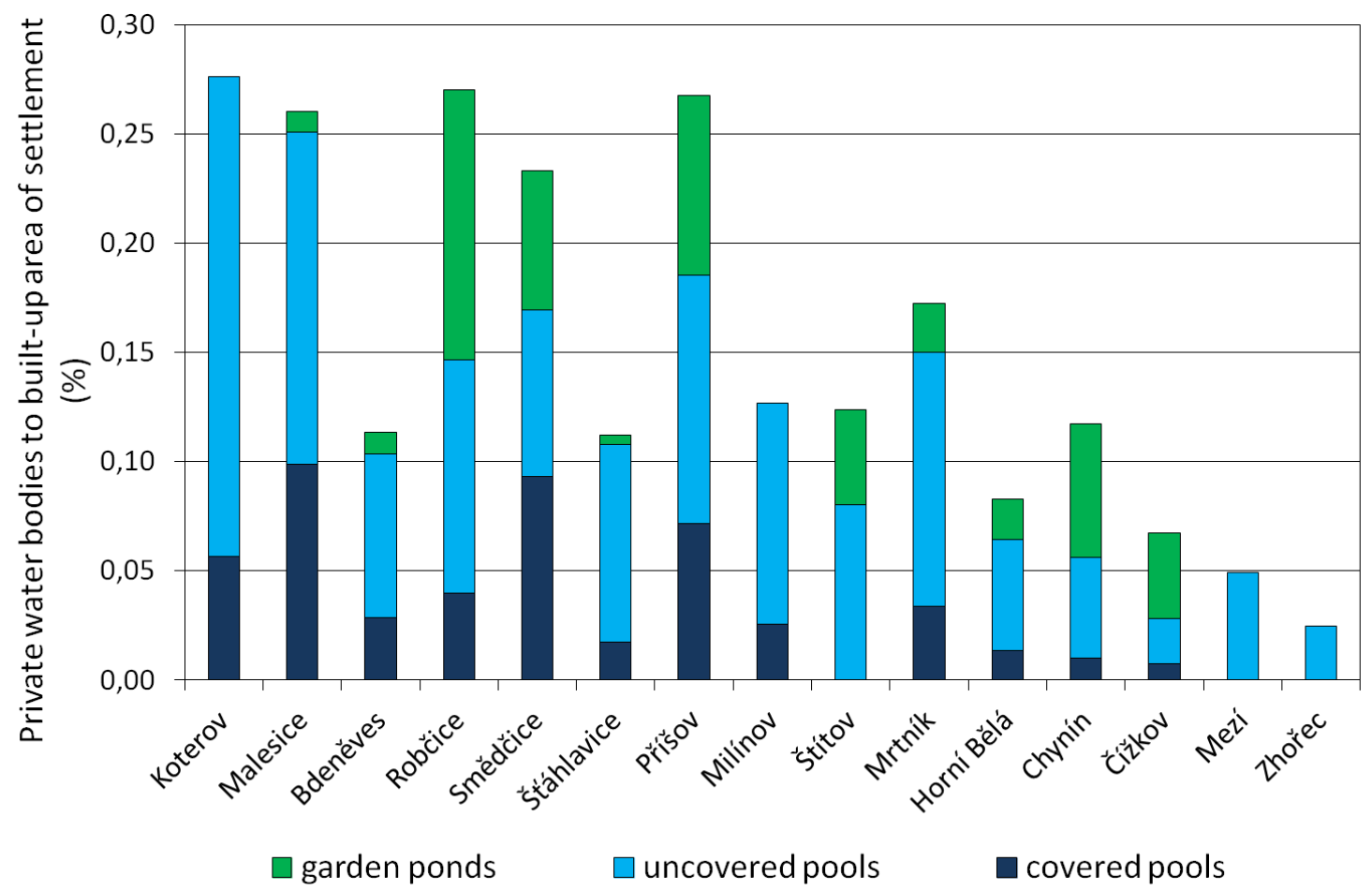

Fig 9. Proportion of private water bodies in the built-up area of settlement (\%). Source: own processing

\section{Conclusion}

The study of selected settlements in the Pilsen Region confirmed that the new phenomenon of their water surfaces are private pools and ponds in private gardens. This phenomenon is present in both city and suburban areas, as well as in rural areas. In the countryside, there are fewer private pools but they still make up a large water surface to be reckoned with in terms of water management. Enhancing gardens with pools and ponds is dependent on the intensity of new construction in villages, with the gradual transformation of rural gardens from production to 
a recreational and ornamental function, as well as with the extension of the recreational function of real estate in the country. Statistical relationships of the factors mentioned above would need to be confirmed by a broader territorial. In our research we identified a relatively significant percent of area devoted to garden ponds, which do far more to strengthen the ecological functions of urban settlements than swimming pools. Based on our field work we identified the declining importance of public water bodies in some settlements. It should be considered whether increased care of small public water bodies would increase their aesthetic, recreational, and community significance.

The impact of pools on water consumption, which we expressed only on the basis of the deficit generated by evaporation, therefore the difference between precipitation and evaporation is needed. Real influence of pools on water consumption will depend on the individual exchange technology of water in swimming pools. An important factor is filling the pool before the season starts. This can overload the capacity of the local water supply forcing water companies to fill tanks with ordered water (Středočeské vodárny 2015). For a more detailed assessment we would have to investigate swimming pool operations, including the assessment of individual water consumption in households in relation to water resources. In communities that are affected by dry season water shortages it is advisable to promote water saving technology such as "water neutral pools", which focus on reducing the need for water and energy use for swimming pools maintenance and lower the use of pool chemicals. Reducing water use can also be done by covering the pool to lower evaporation, increasing recycling in the water filtration system, use of rainwater, and use swimming pool water for other household functions (SPASA 2011).

\section{Aknowledgements}

This research has been supported by the Technology Agency of the Czech Republic Grant OMEGA TD03000343 „Ecohydrological management of urban landscape microstructures“.

\section{References}

[1] Allen, R. G., Pereira, I., S., Raes, D. \& Smith, M. (1998). Crop evapotranspiration. Guidelines for computing crop water requirements [FAO irrigation and drainage paper 56]. Rome: Food and agriculture organization of the United Nations.

[2] Asdrubali, F. (2009). A scale model to evaluate water evaporation from indoor swimming pools. Energy and Buildings, 41(3), 311-319. DOI: 10.1016/j.enbuild.2008.10.001.

[3] Bach, P. (2014). Market data 2013. Brussels: European Union of Swimming Pool and Spa Associations.

[4] Bański, J. \& Wesołowska, M. (2010). Transformations in housing construction in rural areas of Poland's Lublin region - Influence on the spatial settlement structure and landscape aesthetics. Landscape and Urban Planning, 94(2), 116-126. Doi: 10.1016/j.landurbplan.2009.08.005.

[5] Bartoš, M., Kušová, D., Těšitel, J., Kopp, J., Novotná, M., Macháček, J., Moss, L. \& Glorioso, R. (2011). Amenitní migrace do venkovských oblastí České republiky. Kostelec nad Černými lesy: Lesnická práce.

[6] Růžková, J. \& Škrabal, J, eds. (2006). Historický lexikon obcí České republiky 1869-2011. Praha: Český statistický úrad.

[7] Vodovody, kanalizace a vodní toky - 2014. Praha: Český statistický úřad. Available at https://www.czso.cz/csu/czso/vodovody-kanalizace-a-vodni-toky-2014 [Accessed on 12 April 2016].

[8] ČÚZK (2016a). Geoportál ČÚZK. Český úřad zeměměřický a katastrální. Available at http://geoportal.cuzk.cz [Accessed on 2 May 2016]. 
[9] ČÚZK (2016b). Adresní místa RÚIAN ve formátu CSV. Nahlížení do katastru nemovitostí. Praha: Český úřad zeměměřický a katastrální. Available at http://nahlizenidokn.cuzk.cz/StahniAdresniMistaRUIAN.aspx [Accessed on 8 May 2016].

[10] DeOreo, W. B. (2011). Analysis of water use in new single-family homes. Salt Lake City: Salt Lake City Corporation and US EPA.

[11] Domene, E. (2014). Changing patters of water consumption in the suburban Barcelona: lifestiles and welfare as explanatory factors. Investigaciones Geográficas, 61, 39-53. Doi: 10.14198/INGEO2014.61.03.

[12] Domene, E., Saurí, D. \& Parés, M. (2005). Urbanization and Sustainable Resource Use: The Case of Garden Watering in the Metropolitan Region of Barcelona. Urban Geography, 26(6), 520-535. Doi:10.2747/0272-3638.26.6.520.

[13] Duffková, R. (2003). Porovnání hodnot aktuální evapotranspirace travního porostu získaných třemi různými metodami. Acta Hydrologica Slovaca, 4(2), 323-330.

[14] Ferguson, B. C., Fratzeskaki, N. \& Brown, R. (2013). A strategic program for transitioning to a Water Sensitive City. Landscape and Urban Planning, 117, 32-45. DOI: 10.1016/j.landurbplan.2013.04.016.

[15] Frajer, J. (2013). Rekonstrukce historické krajiny Čáslavska s důrazem na vodní hospodářství [Ph.D. thesis]. Ostrava: Ostravská univerzita.

[16] Frajer, J. (2015). Zrušení Druhanického rybníka u Chotusic aneb environmentálně historická mikrosonda. Východočeský sborník historický, 27(1), 103-125.

[17] Goddard, M. A., Dougill, A. J. \& Benton, T. G. (2010). Scaling up from gardens: biodiversity conservation in urban environments. Trends in Ecology \& Evolution 25(2), 90-98. Doi: 10.1016/j.tree.2009.07.016.

[18] Guhathakurta, S. \& Gober, P. (2010). Residential Land Use, the Urban Heat Island, and Water Use in Phoenix: A Path Analysis. Journal of Planning Education and Research, 30(1), 40-51. Doi: 10.1177/0739456X10374187.

[19] Halper, E. B., Dall'erba, S., Bark, R. H., Scott, Ch. A. \& Yool, S. R. (2015). Effects of irrigated parks on outdoor residential water use in a semi-arid city. Landscape and Urban Planning, 134, 210-220. Doi:10.1016/j.landurbplan.2014.09.005.

[20] Havlíček, M., Pavelková, R., Frajer, J. \& Skokanová, H. (2014). The Long-Term Development of Water Bodies in the Context of Land Use: The Case of the Kyjovka and Trkmanka River Basins (Czech Republic). Moravian Geographical Reports, 22(4), 39-50. Doi: 10.1515/mgr2014-0022.

[21] Hof, A. \& Wolf, N. (2014). Estimating potential outdoor water consumption in private urban landscapes by coupling high-resolution image analysis, irrigation water needs and evaporation estimation in Spain. Landscape and Urban Planning, 123, 61-72. Doi: 10.1016/j.landurbplan.2013.12.010.

[22] Hysková, B. (2003). Povodeň z př́valového deště v Sytně 21. 8. 2002. In Obnova území po povodních. Urbanismus a územní rozvoj.

[23] Chang, H., Parandvash, G. H. \& Shandas, V. (2010). Spatial Variations of Single-Family Residential Water Consumption in Portland, Oregon. Urban Geography, 31(7), 953-972. Doi:10.2747/0272-3638.31.7.953.

[24] Jíhlavec, J. (1978). O Kalech. Zpravodaj místopisné komise ČSAV, 14(5), 478-471.

[25] Kohut, M., Hora, P. \& Chuchma, F. (2011). Potenciální evapotranspirace travního porostu v oblasti lokality Pánov na Hodonínsku - dlouhodobé vývojové trendy v období let 19612099. In Středová, H., Rožnovský, J. \& Litschmann, T., eds., Mikroklima a mezoklima krajinných struktur a antropogenních prostředí. Prague: Czech Hydrometeorological Institute. 
[26] Kohut, M., Rožnovský, J. \& Knozová, G. (2013). Měření výparu z vodní hladiny výparoměrem GGI-3000 v České republice. Prague: Czech Hydrometeorological Institute.

[27] Kopp, J. (2007). Vliv antropogenních změn na stabilitu fluviálních systémů (pp. 143-151). In Změny v krajině a povodňové riziko. Praha: Univerzita Karlova v Praze.

[28] Kopp, J. (2015). Integrované přístupy ke strategickému plánování měst - nové trendy péče o vodu. Regionální rozvoj mezi teorií a praxí, 4(4), 21-29.

[29] Kopp, J., Novotná, M. \& Duben, J. (2009). Bytová výstavba v kontextu kvality životního prostředí v České republice v letech 1997-2007. Geografické informácie, 13(1), 87-93.

[30] Kopp, J., Novotná, M. \& Matušková, A. (2013). Rezidenční suburbanizace v plzeňském městském regionu $v$ krajinně-ekologickém kontextu (pp. 150-174). In Ouředníček, M., Špačková, P. \& Novák, J. (eds.) Sub urbs: krajina, sídla a lidé. Praha: Academia.

[31] Loudová, M. (2012). Krajinně-ekologické hodnocení venkovských sídel v obci Řenče [Bachelor thesis]. Plzeň: Západočeská univerzita v Plzni.

[32] MacDonald, D. H., Crossman, N. D., Mahmoudi, P., Taylor, L. O., Summers, D. M. \& Boxall, P. C. (2010). The value of public and private green spaces under water restrictions. Landscape and Urban Planning, 95, 192-200. Doi: 10.1016/j.landurbplan.2010.01.003.

[33] Mousia, A. \& Dimoudi, A. (2015). Energy performance of open air swimming pools in Greece. Energy and Buildings, 90, 166-172. Doi:10.1016/j.enbuild.2015.01.004.

[34] Muir, R. (2004). Landscape Encyclopaedia. London: Windgather Press.

[35] Mukherjee, R., Halder, D., Saha, S., Shyamali, R., Subhranshu, Ch., Ramakrishnan, R., Murhekar, M. V. \& Hutin, Y. J. (2011). Five Pond-centered Outbreaks of Cholera in Villages of West Bengal, India: Evidence for Focused Interventions. Journal of Health Population and Nutrition 29(5), 421-428. Doi: 10.3329/jhpn.v29i5.8895.

[36] Nasar, J. L. \& Li, M. (2004). Landscape mirror: the attractiveness of reflecting water. Landscape and Urban Planning, 66, 233-238. Doi: 10.1016/S0169-2046(03)00113-0.

[37] Ouředníček, M., ed. (2012). Soubor specializovaných map - Rezidenční suburbanizace. Praha: Univerzita Karlova v Praze \& Obec Dolní Břežany.

[38] Ouředníček, M., Špačková, P. \& Novák, J. (2013). Metodické problémy výzkumu a vymezení zón rezidenční suburbanizace v České republice (pp. 309-332). In Ouředníček, M., Špačková, P. \& Novák, J., eds., Sub urbs: krajina, sídla a lidé. Praha: Academia.

[39] Pallarès-Blanch, M., Prados, M.-J. \& Tulla, A. F. (2014) Naturbanization and Urban - Rural Dynamics in Spain: Case Study of New Rural Landscapes in Andalusia and Catalonia. European Countryside, 6(2), 118-160. Doi: 10.2478/euco-2014-0008.

[40] Pospěch, P., Spěšná, D. \& Staveník, A. (2015). Images of a Good Village: a Visual Analysis of the Rural Idyll in the "Village of the Year" Competition in the Czech Republic. European Countryside, 7(2), 68-86. Doi: 10.1515/euco-2015-0005.

[41] Radford, K. G. \& James, P. (2013). Changes in the value of ecosystem services along a rural-urban gradient: A case study of Greater Manchester, UK. Landscape and Urban Planning, 109, 117-127. Doi: 10.1016/j.landurbplan.2012.10.007.

[42] Salvador, R., Bautista-Capetillo, C. \& Playán, E. (2011). Irrigation performance in private urban landscapes: A study case in Zaragoza (Spain). Landscape and Urban Planning, 100, 302-311. Doi: 10.1016/j.landurbplan.2010.12.018.

[43] Shah, M. M. (2012). Improved method for calculating evaporation from indoor water pools. Energy and Buildings, 49, 306-309. Doi: 10.1016/j.enbuild.2012.02.026.

[44] Smallbone, L. T., Luck, G. W. \& Wassens, S. (2011). Anuran species in urban landscapes: relationships with biophysical, built environment and socio-economic factors. Landscape and Urban Planning, 101, 43-51. Doi:10.1016/j.landurbplan.2011.01.002. 
[45] SPASA (2011). Ideas for how you can actively conserve water while still enjoying your swimming pool or spa. Fact sheet 21 savewater! TM SPASA POOL \& SPA BOOK 2011 (27). The Swimming Pool and Spa Association of Victoria. Available at http://www.alpinepools.com.au/pdfs/water_neutral_factsheet.pdf [Accessed on 15 January 2016].

[46] Spilková, J. \& Vágner, J. (2016). The loss of land devoted to allotment gardening: The context of thecontrasting pressures of urban planning, public and private interestsin Prague, Czechia. Land Use Policy, 52, 232-239. Doi:10.1016/j.landusepol.2015.12.031.

[47] Středočeské vodárny (2015). Nastupuje sezóna napouštění bazénů. Available at http://www.svas.cz/tiskove-zpravy/media/2015/nastupuje-sezona-napousteni-bazenu/ [Accessed on 5 May 2016].

[48] Sýkora, L. \& Mulíček, O. (2012). Urbanizace a suburbanizace v Česku na počátku 21. století. Urbanismus a územní rozvoj, 15(5), 27-38.

[49] Syme, G. J., Shao, Q., Po, M. \& Campbell, E. (2004). Predicting and understanding home garden water use. Landscape and Urban Planning, 68, 121-128. Doi:10.1016/j.landurbplan.2003.08.002.

[50] Šimon, M. (2014). Exploring Counterurbanisation in a Post-Socialist Context: Case of the Czech Republic. Sociologia ruralis 54(2), 117-142. DOI: 10.1111/j.14679523.2012.00576.x.

[51] Šusta, J. \& Mokrý, T. (1931). Význam jihočeského rybníkářství, jeho vznik a vývoj. Praha: Československá Akademie zemědělská.

[52] Tolasz, R., ed. (2007). Atlas podnebí Česka = Climate atlas of Czechia. Praha: Český hydrometeorologický ústav.

[53] Váchal, A. (2016). Česká bazénová velmoc roste. Hospodářské noviny, 3. - 5. června 2016, p. 16.

[54] Vidal, M., Domene, E. \& Sauri, D. (2011). Changing geographies of water-related consumption: residential swimming pools in suburban Barcelona. Area, 43, 67-75. Doi: 10.1111/j.1475-4762.2010.00961.x.

[55] VInas, R. (2015). Pozorované změny složek hydrologické bilance z hlediska využitelných vodních zdrojů. Vodohospodárské technicko-ekonomické informace, 2015(4-5), 27-32.

[56] Wolf, N. \& Hof, A. (2013). Integration of the pixel and object domain for the mapping of new urban landscapes in the Mediterranean with a focus on outdoor water consumption. EARSeL eProceedings, 12(1), 67-81. Doi: 10.12760/01-2013-1-07.

[57] Wong, T. H. F., ed. (2013). Blueprint 2013. Stormwater Management in a Water Sensitive City. Clayton: Cooperative Research Centre for Water Sensitive Cities.

[58] Zambon, I., Sabbi, A., Schuetze, T. \& Salvati, L. (2015). Exploring forest 'fringescapes': urban growth, society and swimming pools as a sprawl landmark in coastal Rome. Rendiconti Lincei 26(2), 159-168. Doi: 10.1007/s12210-015-0377-6.

[59] ZMOS (2008). Zásady integrovaného manažmentu vodných zdrojov na území obcí a ich povodí. Združenie miest a obcí Slovenska. 